\title{
ISLAMIC FAMILY AND CHILD PROTECTION LAW'S PERSPECTIVE ON VIOLENCE AGAINST CHILDREN
}

\author{
Beni Chandra ${ }^{1} \&$ Toha Andiko ${ }^{2}$ \\ ${ }^{1}$ Subdit Tipikor, Kantor Kepolisian Daerah Bengkulu \\ Jl. Adam Malik, KM. 9, Kelurahan Sidomunyo, Kecamatan Gading Cempaka, Kota Bengkulu, Propinsi Bengkulu \\ ${ }^{2}$ Program Pascasarjana IAIN Bengkulu, Jl. Raden Fatah Pagar Dewa Bengkulu \\ Email: ${ }^{1}$ dafabeni25@gmail.com; ${ }^{2}$ toha.andiko@gmail.com
}

\begin{abstract}
The Indonesian Government guarantees the rights and protection of children by Act 35 of 2014 concerning Child Protection. The law provides absolute protection for children against physical and psychological violence that they may receive, but on the other hand there is an interest in Moslem's families to educate their children according to Islamic law $(f i q h)$, so that there is a contradiction both of them. This research was conducted to determine the view of Islamic family and positive law on the problem of handling and protecting children and the limits of violence against children. The researchers used a comparative approach and library research method. Based on the research conducted, it is found that Islamic family and positive law go in line to provide protection for children. The differences are in the perspective of "children", violence against children, the application of physical and psychological punishment, and actions against perpetrators of violence. In addition, there are limits to acts of both physical and psychological violence as a preventive and repressive measure against children, according to the provisions of Islamic family law.
\end{abstract}

Keywords: Violence; Children; Islamic Family Law; Child Protection

Abstrak: Pemerintah Indonesia menjamin hak-hak dan perlindungan terhadap anak dalam Undang Undang Nomor 35 Tahun 2014 tentang Perlindungan Anak. Undang-undang tersebut memberikan proteksi absolut kepada anak terhadap kekerasan fisik dan psikis yang mungkin diterimanya, namun di sisi lain terdapat kepentingan keluarga Islam untuk mendidik anak-anaknya menurut hukum Islam $(f q h)$, sehingga terjadi kontradiksi di antara keduanya. Penelitian ini dilakukan untuk mengetahui pandangan hukum keluarga Islam dan hukum positif terhadap persoalan penanganan dan perlindungan anak dan batasan tindakan kekerasan terhadap anak. Peneliti menggunakan pendekatan komparatif (comparative approach) dan studi dokumentasi (library research). Berdasarkan penelitian yang dilakukan, diperoleh hasil bahwa baik hukum keluarga Islam dan hukum positif, keduanya sama-sama bertujuan memberikan perlindungan terhadap anak. Adapun perbedaan di antara keduanya ada pada perspektif tentang "anak" secara definitif, kekerasan terhadap anak, penerapan hukuman fisik dan psikis, dan tindakan terhadap pelaku kekerasan terhadap anak. Di samping itu, terdapat pula batasan tindakan kekerasan baik fisik maupun psikis sebagai upaya preventif dan represif terhadap anak, menurut ketentuan hukum keluarga Islam.

Kata kunci: Kekerasan; Anak; Hukum Keluarga Islam; Perlindungan Anak

\section{Introduction}

The Indonesian government guarantees the rights and protection of children in Law Number 35 of 2014 concerning Amendments to Law Number 23 of 2002 concerning Child Protection. In Article 1 paragraph (1) of the Child Protection Law, it is stated that a child is a person who is not yet 18 (eighteen) years old, including children who are still in the womb. Based on this article, 
children have human values that cannot be eliminated for any reason. Thus the protection of children from violence is an important concern for the government, including in the field of child development. The existence of stages of child development and growth shows that the child as a human figure with the basic completeness that is in him has just reached maturity in life through several processes along with his growing age both at home and in the surrounding environment.

Regard to handling children, there are two steps that are generally taken by parents, namely: preventive steps (before the child violates) and repressive steps (after the child violates). The two steps consist of advice, harsh reprimand, even beatings within the framework of children's education. However, in implementing these steps, parents often clash with positive legal regulations (the Child Protection Act) which provide absolute protection against physical and psychological violence.

The Child Protection Law states that:

"Child Protection means all activities to guarantee and to protect children and their rights so that they can live, grow, develop, and participate optimally in accordance with human dignity and protection from violence and discrimination."

"Violence is any act against a child which results in suffering or suffering physically, psychologically, sexually, and/or neglect, including threats to commit acts, coercion, or illegal deprivation of liberty."

${ }^{1}$ Pasal 1 angka 2 Undang Undang Nomor 35 Tahun 2014 tentang Perubahan atas Undang Undang Nomor 23 Tahun 2002 tentang Perlindungan Anak.

2 Pasal 1angka 15 huruf a Undang Undang Nomor 35 Tahun 2014 tentang Perubahan atas Undang Undang Nomor 23 Tahun 2002 tentang Perlindungan Anak.
"Children in and within the educational unit are required to receive protection from acts of physical, psychological, sexual violence and other crimes committed by educators, educational staff, fellow students, and / or other parties." 3

Noticing some of the articles above, it can be seen that handling naughty children can create a conflict of interest, on the one hand parents and educators should not be silent about the mistakes their children have made, but on the other hand, physical and psychological violence should not be committed against children. In other words, there are some contradictions in the realm of personal interests and expectations of child protection as part of the government's public interest.

The implication of arranging these articles is that many educators (teachers) are affected. Instead of correcting the students' mistakes, the teachers ended up confronting the law on the basis of the preventive and repressive measures they were doing against their students. At another level, not a few parents or family members also collide with the mandate of the law, when they will take preventive and repressive actions that lead to violence against children for the purpose of children's education.

Discussions regarding acts of physical and psychological violence, both at the level of preventive (prevention) and repressive (action of punishment) against children need to be studied in depth and comprehensively so that clear information can be obtained, accepted and applied by Muslim communities

\footnotetext{
${ }^{3}$ Pasal 54 ayat (1) Undang Undang Nomor 35 Tahun 2014 tentang Perubahan atas Undang Undang Nomor 23 Tahun 2002 tentang Perlindungan Anak.
} 
throughout the territory of the Republic of Indonesia.

There are several studie that discuss child or child crimes against the law which were the researchers's prior research, ${ }^{4}$ however, studies that discuss the pattern of child education in Islam are rare in relation to the Child Protection Law. On this basis, the researchers considered that the issues raised were an urgent phenomenon, novelty, and unique.

Based on the background that the authors have explained above, it can be identified the main problems that need to be discussed further, namely how Islamic family law and positive law view the problem of handling and protection of children and how the limits of violence act as preventive and repressive measures that can be enforced against children according to the provisions of Islamic family law.

\section{Research Method}

This type of research is qualitative research, namely research that reflects a phenomenological perspective to understand the meaning of an event and its mutual

4 Penelitian Samuel Fresly Nainggolan, "FaktorFaktor yang Mempengaruhi Penjatuhan Sanksi Pidana terhadap Anak Nakal”, Jurnal Mahupiki, Vol. 2, No. 1, Agustus 2013; Penelitian Muhammad Aenur Rosyid, dkk, "Alternatif Model Penanganan Anak Yang Berkonflik dengan Hukum Melalui Family Group Conferencing (Analisis Yuridis Undang-Undang Republik Indonesia Nomor 11 Tahun 2012 Tentang Sistem Peradilan Pidana Anak)", Jurnal Universitas Brawijaya, Vol. 3, No. 2, Desember 2013; Betania Fransiska Sitanggang, Irma Cahyaningtyas, "Penanganan Perkara Anak Dalam Perspektif Jaksa Penuntut Umum", Jurnal Pembangunan Hukum, Vol. 2, No. 1, 2020. https://doi.org/10.14710/ jphi.v2i1.66-81 influence with humans in certain situations. ${ }^{5}$ This research will be conducted in a specific setting and is context-oriented. ${ }^{6}$ The form is normative juridical, namely research on legal principles.

It employed a comparative approach in which the researchers tried to compare two kinds of legal perspectives in examining the aspects under study. The two legal perspectives referred to are Islamic law (figh) and positive law.

This is descriptive-analytic research in which the researchers tried to explain existing conditions or hypotheses with the aim of finding facts followed by adequate analysis as an attempt to find problem solutions. This study seeks to explain how the concept of child protection against violence in the Child Protection Act, which is then analyzed with the concept of Islamic law related to violence against children as an effort to take repressive measures to find a common ground.

Furthermore, the researchers used the documentation study method in collecting data, so that the study will be carried out by tracing and examining the literature or written sources related to the subject (research focused on library materials).?

As library research, the data collection technique carried out is by tracing data sources or libraries, especially the results of writing, prints, and/or publications related to violence against children, matters related to jinayah principles in the framework of Islamic law,

${ }^{5}$ Asmadi Alsa, Pendekatan Kuantitatif Kualitatif Serta Kombinasinya dalam Penelitian Sosiologi, (Yogyakarta: Pustaka Pelajar, 2014), p. 32-33.

${ }^{6}$ Asmadi Alsa, Pendekatan Kuantitatif ..., p. 39.

7 Abudin Nata, Metodologi Studi Islam, (Jakarta: Rajawali Press, 2010), p. 212. 
and government participation and positive law related to the protection of children in general.

\section{The Perspective of Islamic Family and Positive Law on Children Handling}

In terms of the juridical aspect, the notion of a child is generally defined as a person who is not mature (minderjarig/person underage), a person who is underage/underage (minderjarigheid/inferioriy) or often referred to as a child who is under guardianship (minderjarige ondervoordij). With a starting point of this aspect, Indonesia's positive law (ius constitutum/ius operatum) does not regulate the existence of a universal law unification to determine the criteria for age limits for a child. ${ }^{8}$

The meaning of children here is not only biological children, but also, as confirmed in the explanation of Article 2 paragraph (1) letter a of Law No.23 of 2004, also includes adopted and stepchildren. Thus, the definition of "child" in Law No.23 of 2004 is different from the meaning of "child" according to other laws, for example Law No.23 of 2002 concerning Child Protection. According to Law No.23 of 2002 concerning Child Protection, in Article 1 point 1, a child is someone who is not yet 18 (eighteen) years old, including children who are still in the womb. The definition of "child" in the Child Protection Law is seen in terms of age.'

Child protection is part of national

${ }^{8}$ Ifa Latifa Fitriani, "Islam Dan Keadilan Restroratif Pada Anak Yang Berhadapan Dengan Hukum", IN RIGHT Jurnal Agama dan Hak Azasi Manusia, Vol. 2, No. 1, 2012, p. 209.

9 Taisja Limbat, "Perlindungan Anak Terhadap Kekerasan Menurut Undang-Undang Penghapusan Kekerasan Dalam Rumah Tangga”, Jurnal Lex Crimen, Vol. III, No. 3, Mei-Juli 2014, p. 48. development. Protecting children is protecting humans, and building people as whole as possible. This is reflected in the essence of national development, namely the development of the whole Indonesian human being who is virtuous. Ignoring the issue of child protection means that it will not strengthen national development. The result of the absence of child protection will cause various social problems that can interfere with law enforcement, order, security, and national development. ${ }^{10}$

The difference in perspective between Islamic and positive law in viewing the handling of children is a phenomenon and legal issue that is interesting to research. This issue is becoming increasingly important to discuss so that educators and parents can have guidelines or guidelines in handling children in the family.

Several forms of approaches that involve preventive and repressive measures - even though they are well intentioned - are often confronted diametrically (face to face) with criminal law on the basis of the Child Protection Law. The interest of the Islamic family to educate their children according to Islamic law will be faced with the interests of the government as outlined in the law.

Therefore, it seems clear that the conflict that occurs has the potential to cause legal confusion, ambiguity (multiple interpretations of the law), and legal obscurity within the scope of law enforcement against physical and psychological violence committed by parents in preventive and repressive handling of children. Furthermore, a general discourse

${ }_{10}$ Rio Hendra, "Penerapan Keadilan Restoratif Di Indonesia Bagi Anak Yang Sedang Berhadapan Hukum", Jurnal Surya Kencana Dua: Dinamika Masalah Hukum dan Keadilan, Vol. 5, No.2, Desember 2018, p. 259. 
will be formed which illustrates that Islam is a religion that tolerates beating of children, while positive law protects children more and is more worthy of being a reference than religion, even though in fact it is not the case.

1. Comparison of child protection between Islamic family and positive law

Islam provides guidelines in relation to child protection, namely: First, the Al-Qur'an states that children should not be the cause of poverty for their parents, and parents should not suffer misery because of their children (QS. Al-Baqarah/2: 233) . For this reason, children need to be prepared so that they are ready to face the realities of life and do not always depend on their parents, and do not become a burden for their parents. In addition, children are also not allowed to become a source of slander for their parents. (Surah Al-Taghabun/64: 14-15) This is where good moral education is needed, so that children do not become slander for both parents. On the other hand, the Al-Qur'an requires those children to be entertainers and a source of pride for their families, to be a conditioning for their parents' hearts (Surat al-Furqaan/25: 74). For this purpose, parents are required to be careful in directing and guiding their children. They must be guided and educated to carry out righteous deeds. Second, parents should not cause misery for their children. Children are a mandate entrusted by Allah SWT. to his parents. They must be protected for the safety of their souls, their daily lives, their future, so that they do not become a burden on the compassion of others because they are weak materially or mentally (QS. AnNisa'/4: 9). Therefore, parents and educators are ordered to carry out that mandate and are not allowed to betray them, including caring for children who have been entrusted with it (QS. Al-Anfal/8:27).

Protection of children, in terms of religion, requires religious education for children at home and in educational institutions where they study, in accordance with the religion their parents adhere to, parents and schools must heed this, if it is not, then nature will decorate the self of every human being from birth is not protected. In the context of protection from a religious perspective, children must also be protected from anything that can damage their morals, because religion cannot be separated from it. The growth of children in shaping attitudes, behavior and personality is not only determined by the family, mother and father, but also by reading and the environment. That is the view of religious leaders and scientists. Environmental factors in schools and communities must be in line with or, at least, not in conflict with what is experienced by children in the family environment. Therefore, parents and society must be able to protect children from reading, viewing, and bad environments. In the context of this protection, the government needs to establish laws and regulations that can ensure the protection of children from all negative impacts on their morals and religion.

Even though Islamic and positive law (the Child Protection Law) both have noble goals for children as the next generation, there are still clear differences in perspective between Islamic family and positive law regarding actions against child protection. A striking difference which has the potential to cause chaos in the application of the articles in the future.

On the one hand, Islamic family law provides protection in accordance with the 
portion specified in the Qur'an and hadith, namely protection based on morals, while on the other hand positive law provides protection that is absolute as a form of product based on philosophical or Western-style "modern legal ethics", not based on morals, namely religion. The differences above indicate the closure of the space for the application of physical and psychological punishment to children in positive law, even though there are times when physical punishment and psychological punishment are among the ones that are ordered in Islamic family law and Islamic legal education.

Based on the Child Protection Law, it can be reflected that all actions against children that cause physical and psychological distress are classified as prohibited forms of violence. As for the form of violence against childrenboth physical violence and psychological violence-is an act that violates positive law and must be subject to punishment.

The Child Protection Law was issued starting from the many acts of violence that occurred as a result of the arbitrariness of parents and/or educators in the school environment. Actually there is nothing wrong with this, because the issuance of this regulation is a positive response to protect children from adult injustice. However, according to the researchers' judgment, the law is far from perfect. In addition to having non-actual sanctions to suppress and solve the problem of sexual crimes against children, the law appears to provide for the role of parents and educators who truly stand on Islamic ideals.

It is unfortunate that Article 15 letter a, which contains the definition of violence against children, is not provided with additional information in the elucidation of the article, so that the meaning of violence against children can become multi-interpretations and show absolutism in the position of children in various fields. In fact, every child is a young human being who is attached to mistakes, ignorance, and other omissions.

In fact, neglect of children's rights includes social violence against children. In an inappropriate age, the child has to work hard, which can harm not only physically but also psychologically. Physically, the child's body is not fully developed, the height and weight are not yet optimally developed, the bones are still small and are not able to lift heavy loads, the mind is also immature to accept the work that should be done by adults. This of course can affect the physical development of the child, which may be because they often accept and bear heavy burdens, the child's body develops imperfectly. In addition, children who are supposed to learn to prepare for a bright future, ultimately do not have the opportunity to learn, let alone to play and socialize with their friends. Many of the children's time will be sacrificed because of neglect by parents. ${ }^{11}$

The absolutism of the Child Protection Law in protecting children from physical and psychological violence in general indicates the weak position of parents and educators. There is an impression that acts that lead to violence both physically and psychologically against children fall into the realm of verbooden (forbidden), so the perpetrator must be punished without paying attention to the reasons for the violence.

11 Rianawati, "Perlindungan Hukum Terhadap Kekerasan Pada Anak", RAHEEMA: Jurnal Studi Gender dan Anak, Vol. 2, No. 1, 2015, p. 9. 
The view of positive law on absolute protection of children is diametrically opposed to Islamic family law. Islamic law that makes physical punishment and psychological reprimand against children as preventive or repressive measures for children will be categorized into forms of physical or physical violence against children in the perspective of positive law. For example, in the application of the hadith, the obligation to pray in the hadith is a continuation of the command to pray to children in the Al-Qur'an (QS. Luqman/31:17). Consider some of the following hadiths: ${ }^{12}$

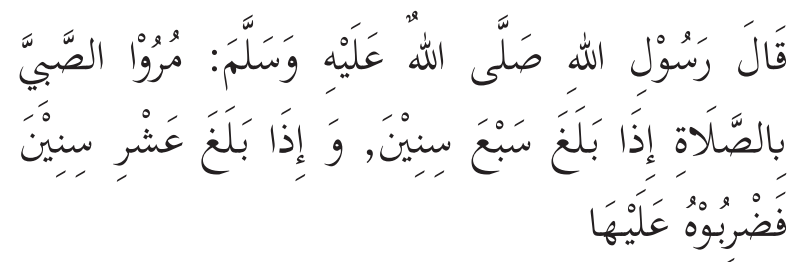

Rasulullah Saw. said, "Instruct a child to pray when he is seven years old. When you reach the age of ten, beat him to pray." (HR. Abu Dawud dari Sabrah bin Ma'bad al-Juhani ra.)

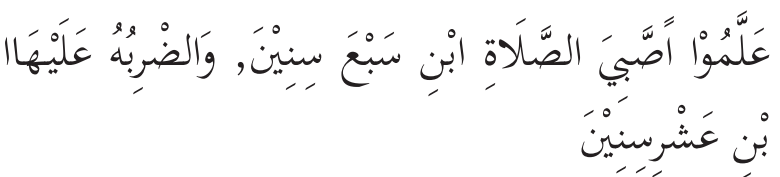

"Teach a child to pray when he is seven years old, and beat him to pray when he reaches ten years of age." (HR. Tirmidzi)

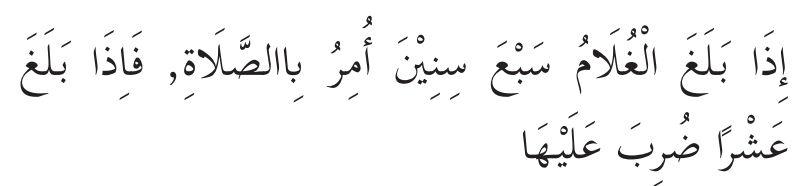

${ }^{12}$ Hadis dari Sabrah bin Ma'bad al-Juhani ra., Abu Dawud, al-Musnad, No. 459, Imam al-Tirmidzi, Tuhfatul Ahwadzi fii Syarh Sunan at-Tirmidzi, Juz II, p. 405. Derajat hasan shahih dalam Kitab Digital Mausu'ah Hadits; 'Aidh al-Qarni, Ensiklopedi Dalil Hukum, (Jakarta: Pustaka Samudera Ilmu, 2005), p. 71; juga di dalam Abu Bakar Jabir al-Jazairi, Minhajul Muslim, Solo: Pustaka Arafah, 2014, p. 365; Muhammad Nur Abdul Hafizh Suwaid, Prophetic Parenting: Cara Nabi Mendidik Anak, (Yogyakarta: Pro-U Media, 2010), p. 355-356.
"When a child has reached the age of seven, he is ordered to pray. And when he reaches the age of ten, then he is beaten to pray." (HR. Ahmad III/404)

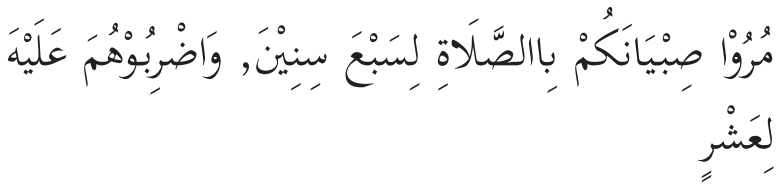

"Order your children to pray at the age of seven, and beat them to pray at the age of ten." (HR. Ad-Daruquthni I/230)

It is also included in other hadith that: ${ }^{13}$

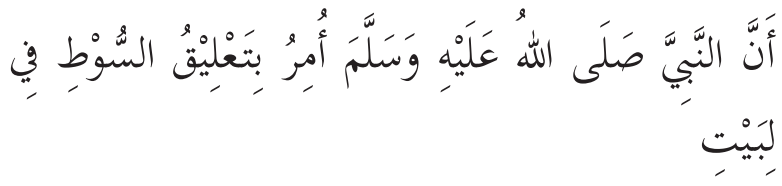
"For the Prophet. ordered to hang the whip in the house." (HR. Bukhari II/656)

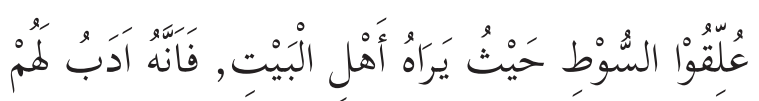

"Hang the whip where your family can see it, for that is (teaching) manners for them." (HR. Abdurrazaq)

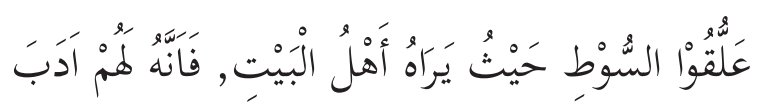
"Hang the whip where your family can see it, for that is (teaching) manners for them." (HR. Thabrani melalui Ibnu Abbas secara marfu')

Regard to frightening children (psychic violence) for the purpose of goodness in religion, Mutawalli asy-Sya'rawi (Grand Shaykh of Al-Azhar University) argued:

"It is not a problem to scare children in religious matters. However, it must also be explained to him about the life of heaventhe reward of goodness that is obtained if he obeys religious orders. As there is a picture given as a result of not passing the exam,

${ }^{13}$ Imam Bukhari, al-Adab al-Mufrad, Imam Thabrani, Shahih al-Jami' ash-Shaghir, nomor hadis 4022, Kitab Digital Mausu'ah Hadits. Lihat juga Hasan Aedy, Kubangun Rumah Tanggaku dengan Modal Akblak Mulia, (Bandung: Alfabeta, 2009), p.128-129. 
thus encouraging him to study hard to pass the exam. Likewise, children who do not go to school for reasons of cold weather. Many people love themselves with stupid love. The first love is love for the long term, and the second for the short term. Everyone loves life. Give a picture to the child of the next life so that he really hopes for heaven and is afraid of hell. On the contrary, it is very dangerous if the child from childhood does not expect heaven and is not afraid of hell. Of course the explanation must be conveyed with full wisdom and through stages. " 14

The application of the hadiths and recommendations above inevitably involves threats and perhaps even beatings as a manifestation of the element of psychological and even physical coercion. So that in fact, religious advice that is divine in nature has the potential to conflict with the provisions stipulated by the Child Protection Law. Article 15 letter a of the law in question states that:

"Violence is any act against a child which results in suffering or suffering physically, psychologically, sexually, and / or neglect, including threats to commit acts, coercion, or illegal deprivation of liberty."

The definition of violence is in line with the meaning of violence in Law no. 23 of 2004 article 1 A which reads: "Violence in the household is any act against someone, especially women, which results in physical, sexual, psychological, and domestic neglect, including threats to commit acts, coercion or illegal deprivation of liberty within the scope of the household".

14 Mutawwali al-Syárawi, Anda Bertanya Islam Menjawab, (Jakarta: Gema Insani Press, 2007), p. 555-556.
On the one hand, the purpose of making regulations that prevent violence is considered good, because it is a preventive effort to protect weak parties in the household so that they are protected from acts of violence by family members. At the same time, it is an effort to deter perpetrators of violence so that they do not repeat their actions. However, in this very detailed regulation, there are criteria for violence that are not in line with the provisions of Islamic law. It is also difficult to limit the size and prove it. ${ }^{15}$

According to the Child Protection Law, violence is defined as any act that targets a child and that act causes misery or suffering, both physical and psychological suffering, including threats. Any form of violence or unpleasant acts that fall into the detailed definition of it, is subject to violence against children. So that coercion with threats and beatings on children aged 10 (ten) years and threats of frightening children with a whip in the house are classified as disgraceful physical and psychological violence.

In Article 76 letter $C$ of the Child Protection Law, it is stated that:

"Everyone is prohibited from placing, permitting, committing, ordering, or participating in violence against children.”

Article 80 paragraph (1) contains the threat of punishment for violating the provisions of Article 76 letter C, which states that:

"Every person who violates the provisions as referred to in Article 76C, shall be sentenced to imprisonment for a maximum of 3 (three)

15 Toha Andiko, "Kekerasan Dalam Rumah Tangga Dan Sanksinya Perspektif Hukum Islam (Studi Kritis UU No. 23 Tahun 2004 Tentang Penghapusan Kekerasan Dalam Rumah Tangga)", Manhaj: Jurnal Penelitian dan Pengabdian Masyarakat, Vol. 6, No. 3, 2017, p. 2 
years and 6 (six) months and / or a maximum fine of Rp72,000,000.00 (seventy two million rupiah)."

On the basis of these articles, the application of the Sunnah on punishing children-which is one of the instruments of Islamic law - becomes inapplicable in Islamic families in Indonesia. In fact, the methods mandated by the Hadith that the researchers mentioned earlier are part of the tarbiyah in the Islamic family which are spiritual in nature and aim to respect the human being himself so that he can be directed with valid directions as the deeds loved and blessed by Allah SWT.

2. Comparison of the benefits and disadvantages of the prohibition of physical and psychological violence against children

State laws and Islamic law basically agree that children must be protected by their rights and interests, and vice versa, it cannot be justified in any form of violence committed against children that could endanger their life and future. ${ }^{16}$

Positive law rejects physical violence absolutely (in absolute terms), arguing that this method of sanctions contains more harm than good. The benefit of staying away from physical violence according to the positiveists is to provide the widest possible space for children to express themselves without having to be under the shadow of psychological and physical threats. In fact, if we look further, the legal absolutism adopted by the Child Protection Law contains several disadvantages. The losses that arise in this case can be in the form of a lack of respect and obedience to

16 Yusdani, Menuju Fiqh Keluarga Progresif, (Yogyakarta: Kaukaba Dipantara, 2015), p. 133. parents and educators, because respect comes after obedience, and obedience is born when there is fear as one of the pillars. Another disadvantage is that there is an attitude of indifference to the orders and prohibitions of parents or educators, because anyone who feels safe from the threat of punishment/sanctions will undoubtedly do whatever he wants. In addition, attitudes against discipline, rules, and decisions taken by parents and educators can emerge, even to the level of fighting parents and fighting with educators. Furthermore, the disadvantages that can arise from absolutism are the emergence of the habit of prioritizing one's own desires, even though it is detrimental to others and a lack of habituation to being patient.

After looking at the description above, the researchers can emphasize that the act of the Child Protection Law which does not provide space for parents and educators to intervene against children's mistakes by means of psychological and physical violence is a fundamental mistake. This is because physical and psychological punishment is clearly known in the Islamic family and in the world of Islamic education. Physical and psychological punishment is applied as a last resort when reprimands and advice can no longer change the wrong behavior of a child.

Researchers see that there is a misunderstanding of the law in translating the word "violence" with the meaning of "violence". Positive law perceives the word "violence" as "violence" which is considered to be increasingly with "cruelty" which connotes crime. So the researchers argues that the legislators should understand that the actions that are prohibited should be "felonies" (cruelty), not violence. This is because all forms 
of law violations that claim children who have been abused - beating, rape, harassment, etc. against children, including teacher beatings against students-are manifestations of acts of cruelty (felonies), not violence. There is always a visible difference between beating that targets a child in the framework of punishment as a remedy and beating that targets the child in terms of just the release of anger.

In Islam, the purpose of requiring punishment, in this case including its punishment, is no different from the general objective of Islamic law, namely creating and maintaining the benefit of mankind, in order to achieve happiness in the world and the hereafter. According to research by scholars, there are two kinds of purposes of punishment. First, the relative goal (al-ghard al-qarîb), which is to punish (inflict pain on) the perpetrator of a criminal act-which in general can encourage the perpetrator to repent-so that he becomes a deterrent, does not want to repeat doing jarim, and other people do not. dare to follow in his footsteps. Second, the absolute goal (al-ghard $a l-b a^{\prime} i d$ ), namely to protect the public benefit. These two things are what every punishment in Islam is trying to achieve. ${ }^{17}$ Therefore, not all violence must be criminalized.

Violence and gentleness are the Sunnah of life, both of them must exist without denying their respective roles. Like human organs, there are hard parts like teeth and soft parts like lips, all of which have their respective roles and functions and all of them cannot negate one another. So it can be said that there are times when a phenomenon in this life will be

${ }^{17}$ Toha Andiko, "Reinterpretasi Sanksi Pidana Islam (Studi terhadap Pemikiran Prof. KH. Ibrahim Hosen, LML)", Jurnal Madania Vol. XVII, No. 2, Desember 2014, p. 236. handled smoothly with just tenderness and there are also complicated events that must be dealt with by means of violence. The same condition can occur in dealing with children.

Even more extreme, it can be explained that psychological violence (threats) and physical violence that may arise in the process of children's education is actually a form of protection itself. Violence must remain, because it is a protection against children from making the same mistakes in the future, protection from ignorance of thought, and guidelines that can lead children to the right path while avoiding evil.

A father hitting his child's leg or a mother twisting his child's ear are both in the final stage of child education in which the child can no longer understand verbal languages. Likewise, when a teacher punishes a student, the teacher is trying to get the student to take lessons so that he does not repeat similar mistakes in the future. Physical and psychological punishment, if applied with the right methods and tools, then this type of sanction will be useful to rectify a child who made a mistake.

To make it easier for readers, researchers have compiled several comparisons of perceptions between Islamic law and positive law in addressing children's problems in the following table form:

Table: Comparison of Islamic Family and Positive Law in addressing child protection, physical violence, and psychological violence

\begin{tabular}{ccc}
\hline Parameter & $\begin{array}{c}\text { Islamic Family } \\
\text { Law } \\
(\text { Fiqh })\end{array}$ & $\begin{array}{c}\text { Positive Law } \\
\text { (Child } \\
\text { Protection } \\
\text { Law) }\end{array}$ \\
\hline $\begin{array}{c}\text { Definition } \\
\text { "child" }\end{array}$ & Under baligh. & $\begin{array}{c}\text { Under 18 years } \\
\text { old. }\end{array}$ \\
\hline $\begin{array}{c}\text { Protection on } \\
\text { Children }\end{array}$ & Cumpulsory & Cumpulsory \\
\hline
\end{tabular}




\begin{tabular}{|c|c|c|}
\hline Parameter & $\begin{array}{c}\text { Islamic Family } \\
\text { Law } \\
(\text { Fiqb })\end{array}$ & $\begin{array}{l}\text { Positive Law } \\
\text { (Child } \\
\text { Protection } \\
\text { Law) }\end{array}$ \\
\hline $\begin{array}{l}\text { Affection to } \\
\text { Children }\end{array}$ & Cumpulsory & Cumpulsory \\
\hline $\begin{array}{c}\text { Violence against } \\
\text { Children }\end{array}$ & $\begin{array}{l}\text { The law of } \\
\text { origin is } \\
\text { forbidden, } \\
\text { until there is an } \\
\text { emergency that } \\
\text { allows it. }\end{array}$ & $\begin{array}{c}\text { Under any } \\
\text { circumstances, } \\
\text { violence against } \\
\text { children, both } \\
\text { physical and } \\
\text { psychological, } \\
\text { is absolutely } \\
\text { prohibited. }\end{array}$ \\
\hline $\begin{array}{l}\text { Punish children } \\
\text { physically } \\
\text { (hit) }\end{array}$ & $\begin{array}{l}\text { Tentative } \\
\text { considering the } \\
\text { condition with } \\
\text { the measure } \\
\text { of emergency } \\
\text { as ultimum } \\
\text { remedium } \\
\text { (highest } \\
\text { penalty). }\end{array}$ & $\begin{array}{l}\text { Absolutely } \\
\text { prohibited, } \\
\text { because } \\
\text { punishment } \\
\text { is classified } \\
\text { as physical } \\
\text { violence. }\end{array}$ \\
\hline $\begin{array}{l}\text { Punish children } \\
\text { psychologically } \\
\text { (threatening, } \\
\text { boycotting, } \\
\text { frowning) }\end{array}$ & $\begin{array}{c}\text { Mubah/allowed } \\
\text { based on the } \\
\text { hadith. }\end{array}$ & $\begin{array}{c}\text { Absolutely } \\
\text { prohibited, } \\
\text { because the } \\
\text { punishment } \\
\text { is classified as } \\
\text { psychological } \\
\text { violence. }\end{array}$ \\
\hline $\begin{array}{c}\text { Perpetrators of } \\
\text { violence against } \\
\text { children }\end{array}$ & $\begin{array}{c}\text { Classified as a } \\
\text { jarimah, except } \\
\text { as the highest } \\
\text { punishment, } \\
\text { the law is } \\
\text { mubah/ } \\
\text { permissible. }\end{array}$ & $\begin{array}{c}\text { Convicted } \\
\text { because it } \\
\text { is a form of } \\
\text { violation of the } \\
\text { law (Article } 76 \mathrm{C} \\
\text { jo. Article } 80 \text { ) }\end{array}$ \\
\hline
\end{tabular}

The table above is the result of comparing the two poles of law in looking at the issue of child protection. Based on this table, it can be seen that there are a number of similarities and differences related to the formulation of the problem raised. The similarity between Islamic family and positive law in terms of viewing child protection lies in the obligation to protect and provide affection for children. However, there are several striking differences between the two, mainly related to the definition of children, the law of violence against children, physical and psychological punishment against children, and the legal status of the perpetrator of violence against children.

\section{Limitation of Violence as a Preventive and Repressive Effort against Children according to the Provisions of Islamic Family Law}

1. Comparison of the impact of violence on children's education

a. Positive and negative impacts of violence against children in positive law

Both physical punishment and psychological sanctions in the framework of violence against children have positive and negative impacts from a positive legal perspective. The positive impact is that there is a guarantee of freedom for a child to be free from all forms of violence that may arise from all forms of action.

Violence against children that appears is often seen as the cause of children not wanting to accept the truth and tend to fight behind the child's boredom and anger. ${ }^{18}$ According to a positiveist understanding, a child should have the widest possible freedom to express what he wants and what he understands to be his right. However, from the positive impacts stated above, the researchers sees that the positive law has not been completed in the discussion of the body of the Child Protection Law.

Referring to the definition of the law that a child is a human being in the womb until the age of 18 (eighteen) years, the act of granting the widest possible freedom of expression will backfire on the child himself. This is even more so if the child has entered adolescence to the age of puberty.

18 Syauqi Muhammad Yusuf, Seindah Kehidupan Surgawi: Manajemen Rumah Tangga Sesuai Tuntunan Islam, (Yogyakarta: Mitra Pustaka, 2014), p. 39. 
During the growth period, children and adolescents will go through various phases of life. Each phase requires different treatment. In other words, each phase requires education which cannot be spared from two things, namely: reward and punishment. Children who are given rights solely in the form of state protection from violence as widely as possible are the same as eliminating guidance (directions), which are what children need.

It is possible that the absolutism of the articles of protection from physical and psychological violence contained in the Child Protection Law will be effective for preschoolers, elementary school children, and secondary schools. However, the loading of articles in the legislative product will not be effective in the world of education if the application is applied to children entering adolescence where advice is no longer optimal for changing behavior.

\section{b. The positive and negative impacts of} violence against children in Islamic law

Prophet Muhammad SAW. divides the stages of child development into three stages: childhood filled with love (mahabbah), addibhu period which is full of guidance in shaping discipline and morality, and shohibhu period where children are treated as friends. ${ }^{19}$ So that the handling of children who deviate also requires variations and adjustments. These variations and adjustments are also included in the aspect of providing preventive and / or repressive measures against the child who is at fault.

From an early age, children must be formed

19 Jalaluddin, Mempersiapkan Anak Saleh: Telaah Pendidikan terhadap Sunnah Rasulullah Saw. Jakarta: Srigunting (PT. RajaGrafindo Persada, 2012), p. 117-121. and accustomed to good habits. Children who make mistakes should be advised even to be treated firmly. Bad effects will occur for the child's personality, if he does not get advice or firm treatment. Fair and strict punishments in the world of education must be enforced when necessary.

Physical and psychological violence given to children within the framework of education is not always perceived as bad, because there are many positive impacts that accompany it. The positive impact in question can be in the form of high awareness of the child, development of maturity level, disciplinary education, and as therapy for the child's development and development journey. Physical punishment in the form of beatings can be a means of bringing success if it is carried out at the right time and place. Beatings in the framework of tarbiyah, will have both short and long term effects.

This is reflected in the behavior of children who are loyal to the orders and prohibitions that are presented to them. This will become a habit that he will live up to adulthood. Although at first children obey orders and prohibitions for fear of punishment, later this fear will turn into an attitude of respect and respect for others such as parents, teachers, and other educators. Obedience can be established when there is fear as one of the pillars. An attitude of fear and respect breeds continuous obedience.

The only negative impact of physical and psychological punishment on children in Islamic families is when parents or educators mistakenly carry out the punishment, neglect to pay attention to how the punishment is given, and lose direction in the method of punishing the child. In other terms, as long 
as the sanction is implemented in accordance with religious boundaries and is used when all methods of teaching are unsuccessful, then physical punishment in the form of beatings will work effectively.

Physical violence if it is done excessively can turn into a means of destruction, but if it is used carelessly or it is less than tolerable, it will be useless. Karsam can be one of the appropriate means of learning if it is in accordance with the syar'i structure.

2. Reasons for permitting violence in children's education

a. The need for violence in children's education

In fact, researchers are a group that agrees that both physical and psychological sanctions can be applied to children and students at certain levels of education, but researchers emphasize that the sanctions for violence will not have a positive impact unless there are causes and motives that encourage the application of these sanctions.

Some of the reasons for permitting physical violence in tarbiyah are:

1) When the method of motivation and encouragement has been tried, but it does not produce results (QS. At-Taubah/9: 20-22);

2) When the gratification and advisory methods were in place, it didn't work (QS. Al-Hujurat149: 9);

3) When the rejection method (boycott) has been implemented, but has not met any results (QS. An-Nuur/24: 2-4);

4) When the method of threatening (psychological violence) has been implemented, but it does not work (QS. Al-Ahzab/33: 60);
5) When parents or educators are truly able to predict there is a positive impact behind the physical sanctions given.

For certain cases, there may be a small proportion of children who still do not experience improvement even though all the teaching methods have been given. However, that does not mean that the reason for meekness becomes an obstacle to the application of the method of physical violence sanctions.

\section{b. Syar'i arguments that allow the sanction of violence in Muslim families}

In general, there are several arguments that indicate that physical sanctions in the form of beatings are allowed. The general arguments referred to include:

1) The beating of the nusyuz woman in the Al-Qur'an An-Nisaa'l4: 34 that states:

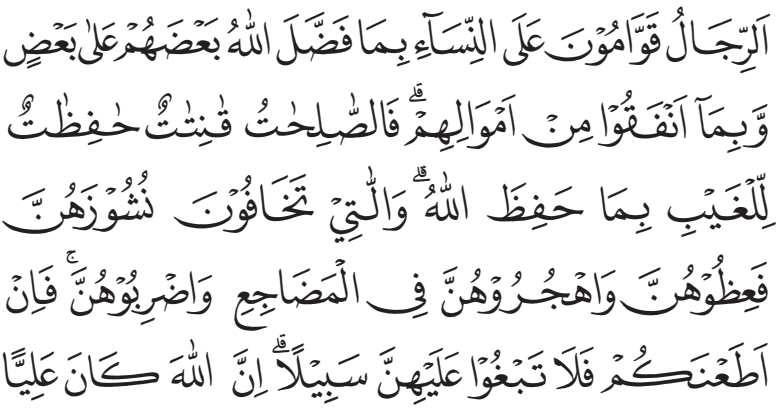

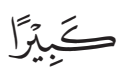

"Men are leaders for women, because Allah has exaggerated some of them (men) over some others (women), and because they (men) have spent part of their wealth. Therefore, a godly woman who is obedient to God takes care of herself when her husband is not there, because God has taken care of (them). Women whom you are worried about nusyuznya, so advise them and separate them in their beds, and beat them. Then if they obey you, then do not look for ways to trouble them. Verily Allah is Most High, Most Great."

Ibn Kathir stated that the lafazh verse " and beat them” is done if advice and 
separation of beds do not thrill him, then it is permissible to beat him without injuring him. As the message of the Prophet Muhammad, in the Hajj Wada', namely:

"The word of Allah ta'ala, 'And beat them'. Namely, if the wife does not leave her bad deeds after being advised and boycotted, then you can hit her with a blow that does not hurt, as it was stipulated in shahihain, from Jabir, from the Prophet. He said in the Hajj wada, Fear Allah in the affairs of women, because their being by your side is a difficult test. It is your right and their duty that they should not have anything to do with anyone in your bed. If they do, then hit them without hurting them. Meanwhile, they get sustenance and clothing in ma'ruf. "The jurisprudents say" A blow that does not hurt is one that does not break the bone and leaves a mark." 20

The Quraish Shihab states that the verse lafazh (واضربوهنّ) is taken from the word Dharaba which has many meanings. Language, when used in the sense of hitting, is not always understood to mean hurting or committing

${ }^{20}$ Muhammad Nasib ar-Rifa'i, Ringkasan Tafsir Ibnu Katsir (Jilid 1), (Jakarta: Gema Insani., 2009), p. 705. In the Interpretation of the Ministry of Religion of the Republic of Indonesia it is also stated: "How should a husband behave towards a wife who does not obey him (nusyuz), that is, to advise her well. If that advice doesn't work, then the husband tries to separate the bed from his wife, and if it doesn't change too, then hit her with a light blow that doesn't hit them and doesn't leave a mark (p. 164). Against a wife who is disobedient to her husband can be done the following actions: To be advised, to separate from bed, or to be beaten with light blows, for the purpose of being educated. "Departemen Agama Republik Indonesia, Al-Qur'an dan Tafsirnya (Jilid II), Jakarta: Lembaga Percetakan Al-Qur'an Departemen Agama, 2009, p. 163-164. In Jalalain's Tafseer it is said: "واضربوهن (And beat them) ie blows that do not hurt, if they are still unconscious". Imam Jalaluddin al-Mahali \& Imam Jalaluddin as-Suyuthi, Terjemahan Tafsir Jalalain Berikut Asbaabun Nuzuul (Jilid 1), (Bandung: Sinar Agung Algensindo, 2006), p. 345. a harsh and harsh action. The purpose of striking in this verse is hitting which does not hurt. The Quraish shihab wrote:

"Do not also say that hitting is no longer relevant today, because education experts still admit it - for certain cases - even among the military it is still known for those who violate discipline, and once again it must be remembered that beatings are ordered (religion) and it (a hit) which is neither injurious nor painful. " 21

With regard to this issue, the interpretation of Fi Zhilalil-Qur'an also finds the statement that:

"And beat them. In line with the intent and purpose of all actions in advance, this beating is not intended to hurt, torture and satisfy oneself. This beating must not be carried out with the intention of humiliating or degrading. Nor should it be done harshly and harshly to submit to a life which one does not like. The beatings that are carried out must be in the context of educating, which must be accompanied by a feeling of affection from an educator, as is done by a father to his children and by a teacher to his student. "22

2) The blow of the Prophet Ayyub as., to his wife in the Qur'an Surah Shaad/38: 44 which reads:

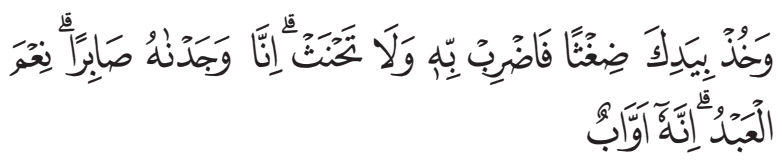

"And take with your hands a bunch (of grass), then beat with it and do not break your oath. Indeed, we found him (Ayyub) a patient. He is

21 Quraish Shihab, Tafsir Al-Mishbah: Pesan dan Keserasian Al-Qur'an (Volume 2), (Tangerang: Lentera Hati, 2008), p. 432.

${ }^{22}$ Sayyid Quthb, Tafsir Fi Zhilalil Qur'an: Di Bawah Naungan Al-Qur'an (Jilid 2), (Jakarta: Gema Insani, 2011), p. 358. 
the best servant. Indeed he is very obedient (to his God)."

Ibn Kathir states in his tafisir this verse $($ وَخَّ

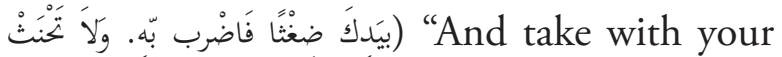
hands a bunch (of grass), then beat it (your wife) and donst break your oath."

"So Allah SWT., gave a fatwa to him to take a bunch of grapes totaling one hundred and then hit his wife once. In this way, he has performed his sumah and he is freed from his vows and has perfected his nadzâ. This also includes relief and a way out of those who repent and repent to Him." ${ }^{23}$

The interpretation of the Ministry of Religion of the Republic of Indonesia states that:

"The verse of the Al-Qur'an does not say what because he took an oath and what was his oath. Only the Hadith states that he swore because his wife, whose name was Rahmah bin Ifraim, went out for something and came late. Ayyub vowed to hit him 100 times when he was healed. With the beating of the bundle of grass, he was deemed to have carried out his oath, as a mercy for Job himself and for his wife who had served him well in times of illness. With the mercy of God, even that Job was spared from breaking his oath. " 24

${ }^{23}$ Muhammad Nasib ar-Rifa'i, Ringkasan Tafsir Ibnu Katsir (Jilid IV), (Jakarta: Gema Insani, 2000), p. 79.

${ }^{24}$ Departemen Agama Republik Indonesia, Al-Qur'an dan Tafsirnya (Edisi yang Disempurnakan), Jakarta: Lembaga Pencetakan Al-Qur'an Departemen Agama, 2009, p. 381. The meaning of the Interpretation of the Ministry of Religion, Tafsir Jalalain also states: "(And take it with your hands), namely a bunch of thatch grass or a bunch of twigs, (then hit with it) your wife, because the Prophet Ayyub once swore that he would beat his wife as much as a hundred. times cries, because one day he never did not obey his orders. (And do not break your oath) by not beating him, then the Prophet Ayyub took a hundred stalks without hitting him, then the Prophet Ayyub took a hundred sticks of Idzkir wood or other wood, then he
Regard to the same verse, the Quraish Shihab stated:

According to history, the Prophet Ayyub as., Once vowed to beat a member of his family there is a history that states his wife - because his family had done something that irritated the Prophet Ayyub as However, he regrets that his religion is not known as kaffarat as in the Shari'a taught by the Prophet Muhammad. Read QS. Al-Maaidah/5: 89). So, for that, Allah gave him a way out so as not to break his oath, namely to take as much grass as he swore to beat his family. Thus, the Prophet Ayyub as., Carried out his oath but in a way that was not painful. ${ }^{25}$

The evidence that can be learned from the two verses above is that Allah swt. does not command anything except in it there is good and good for the individual and society. Allah SWT. ordered the execution of His punishments of which physical sanctions were a part. Allah SWT. knowing that punishment can thrill and drive (humans) from falling into abominations. This kind of corporal punishment falls within the scope of tarbiyah (education), because education stands on two pillars that support it: reward and punishment.

3) Spanking can be done in addition to hitting the face, the argument is based on several hadiths that the researchers has put forward, one of which is:

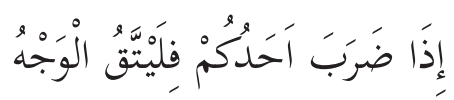

hit his wife with one hit. "Imam Jalaluddin al-Mahalli and Imam Jalaluddin as-Suyuthi, Translation of Jalalain's Interpretation Following Asbaabun Nuzuul (Volume 3), (Bandung: Sinar Baru Algensindo, 2009), p. 1972.

25 Muhammad Quraish Shihab, Tafsir Al-Mishbah: Pesan dan Keserasian Al-Qur'an (Volume 2), (Tangerang: Lentera Hati, 2008),.h. 152-153 
"If one of you hits, (then) stay away from (hitting) the face." (HR. Bukhari, in chapter al-Hudud, HR. Muslim, chapter al-Birr) ${ }^{26}$

The face is the most noble member of the human body, therein lies good looks or beauty. The face is also the most influential member of the body. Hence, one disgrace on the face may well be equal to various disgrace on the whole body. Just as the face is the most sensitive part of the body physically, it is also the part of the body that has the most psychological influence. On that basis, the Prophet Muhammad. ordered to stay away from blows to the face.

4) The hits can be made no more than ten times

Hits that exceed ten times can only be done for violations of the law (budud) of Allah SWT. In the Bukhari and Muslim Hadith, it is stated that:

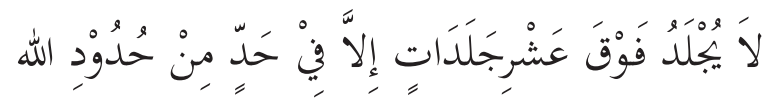
"A person may not be flogged more than ten times unless he violates one of Allah's hududs." (HR. Bukhari from Abu Burdah al-Anshari). ${ }^{27}$

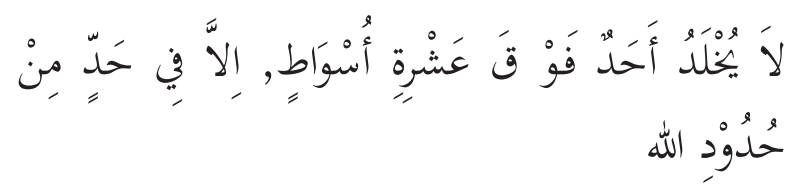

"A person may not be flogged more than ten times, except in the hadd law (which is related)

${ }^{26}$ Abu Abdullah Muhammad bin Ismail al-Bukhari, Ensiklopedi Hadits Jilid II: Shahih Bukhari 2, Jakarta: Almahira, 2012, p. 714 (Bab Batasan Ta'zir dan Hukuman untuk Tujuan Mendidik, nomor hadis 6848), Muslim bin al-Hajjaj al-Qusyairi al-Naisaburi, Ensiklopedia Hadits Jilid IV: Shahih Muslim 2, (Jakarta: Almahira, 2007), p. 572 (al-Mu’jam 32, Bab Larangan Memukul Wajah [atTuhfah 32], nomor hadis 6651-6656).

${ }_{27}$ Abu Abdullah Muhammad bin Ismail al-Bukhari, Ensiklopedi Hadits Jilid II: Shahih Bukhari 2, Jakarta: Almahira, 2012, p. 714. (Bab 42: Batasan Ta'zir dan Hukuman untuk Tujuan Mendidik nomor hadis 6848, 6849, 6850). to the rights of Allah" (HR. Muslim from Abu Burdah al-Ashari). ${ }^{28}$

5) Spanking can be used as the only form of final and highest sanction - known as ultimum remedium in the legal world - to correct mistakes.

Islam has its own guidelines in dealing with violence against children. The law of origin of violence against children is haram, however legal changes can occur in several circumstances, for example in the world of tarbiyah (learning). In short, physical violence (beatings) and psychological violence (threats) are things that were originally prohibited (mahzhurat), but in an emergency for educational purposes, they can be justified. The level of emergency that is intended, can be measured within the limits of the minimum need without giving leeway and addition or being excessive. It is not permissible to create flexibility that goes beyond the boundaries of urgent needs or, for example, enters tertiary needs (tahsiniyat) into urgent needs (dharuriyat) as mandated by the Al-Qur'an Surah Al-Baqarah/2: 173" ${ }^{29}$

According to Wahbah az-Zuhaili, the emergency condition is in the interest of humans who are allowed to use something that is prohibited, because that interest occupies the top of the interests of human life, if it is not implemented it will cause damage. ${ }^{30}$

${ }_{28}$ Muslim bin al-Hajjaj al-Qusyairi an-Naisabur, Ensiklopedi Hadits Jilid IV: Shahih Muslim 2, Jakarta: Almahira, 2012, p. 124. (Mu'jam 9: Bab Batasan Hukuman Ta'zir - at-Tuhfah 20, nomor hadis 4460).

${ }^{29}$ Muhammad Abdul Fatah al-Bayauni, Fikih Darurat: Pegangan Ilmiah Menjawab Persoalan Khilafiah, (Jakarta: Turos, 2018), p. 160.

30 Muchlis Usman, Kaidah-kaidah Ushuliyah dan Fiqjhiyah, (Jakarta: PT. RajaGrafindo Persada, 2009), p. 135. 
In this case, the improvement of children in education is an emergency, it is related to hifz ul-aql (keeping the mind) which is one of the five fundamental protections in Islam.

Figh rules state that:

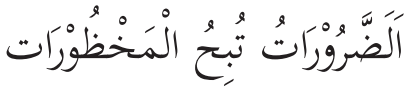

"Emergency conditions allow something to be prohibited."

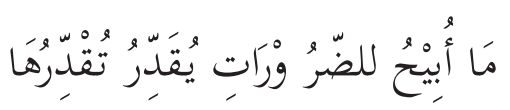

"What is allowed because of an emergency is measured only for its emergency."

The two principles above actually restrict humans from doing what is prohibited due to an emergency. ${ }^{31}$ These principles also require that the permissibility of violence in question is intended to solve difficult problems for parents and educators, where both are unable to control the difficult situation and there is no other choice but to do so. In this case, it is permissible to commit educational violence for the good and protection of the child's future.

Parents and educators are justified in making beatings as a form of physical violence in accordance with the provisions of syara' with the sole purpose of improving the child by paying attention to two things:

a) It is permissible to commit violence while still having to maintain oneself (introspection) so that it does not come out of the meaning of the word "modest emergency". ${ }^{32}$ When children follow directions after physical or psychological abuse, this last method must be stopped.

\footnotetext{
${ }^{31}$ A. Djazuli, Kaidah-Kaidah Fikih, (Jakarta: Kencana Prenada Media Group, 2011), p. 73.

32 Abdul Karim Zaidan, Al-Wajiz, (Jakarta: Pustaka Al-Kautsar, 2008), p. $111 \& 119$.
}

b) There is no other way that can be taken to correct the mistake or in which the other route did not meet the expected results;

Apart from the two dharuriyah principles above, the principle of acting according to intention must also have a place in this discussion, namely:

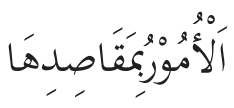

"All actions are dependent on the intention."

The relations between the rules of intention and this problem can be described by the researchers as follows: Whereas physical and psychological violence received by children as a form of punishment must really aim to improve the child in the future, not make the child the target of emotional discharge. This step can only be taken if other methods are not effective in correcting children's deviant behavior, in other words as a last option (ultimum remedium) to correct children's mistakes.

Children who are punished after making mistakes, must be told their mistakes, then it is hoped that he can change to be wiser and understand the direction. This kind of repair will clearly be different from a child who has never been punished for a mistake he has made.

Based on the arguments and principles above, a conclusion can be drawn that the sanction of physical violence in the form of a blow is an inseparable part of the tarbiyah instrument in Islam which has legitimacy in Islamic family law. Apart from that, it cannot be separated from the customs that have occurred in Indonesia since the past. 
3. Sociological reasons for allowing violent sanctions

The Child Protection Law was issued on the basis of the spread of child victims in sexual crimes that occur in society, it is not intended to change the social order in which society is the subject that best understands the goodness of an illiteral rule (custom) that applies in society. in society. Indonesian society is accustomed to educating children by advising, reprimanding, threatening, and beating according to their level. So socially, with the need for psychological and physical violence to improve children, it seems that such violence cannot be eliminated by the issuance of these legislative products.

Violence sanctions given both psychologically and physically will actually shape children and adolescents, so that an attitude of respect for regulations, decisions, orders and prohibitions is born. It can also prevent children from being careless in doing / leaving something except after thinking about the consequences. Violent sanctions can also instill a habit of returning to haq (truth), abandoning mistakes, and preventing dragging into mistakes. In addition, he can also familiarize children or adolescents with being patient and careful.

\section{The limitation of tolerance in Islamic law on violence against children}

Islam tolerates physical and psychological violence for the purposes of enforcing sharia (maqashid al-syariah). The punching sanction in question is carried out as the last means of educating the child. It has entered into the realm of dharuriyat law and must function as an ultimum remedium (the last choice of the existing levels of punishment). Allah SWT. which stipulates sanctions for physical violence (hitting) for the purpose of ta'dib (teaching $a d a b$ ) which is the main element of education. However, Allah SWT. prohibits the sanction of blows that are carried out without haq or arbitrarily so that it goes out of its purpose. Children who receive punishment must first be informed of their mistakes, so that on this basis they will realize the mistakes and violations they have committed.

The sanctions should be carried out at the right time and time, equipped with the right facilities. Corporal punishment of children, in any case, must be neither dangerous nor harmful.

There are several things that need to be considered as a condition for punishing children in Islamic family law

a. Children must first be given a warning before punishment is carried out, and punishment must be in accordance with the mistakes committed, both in terms of quantity and quality;

b. The punishment is carried out immediately after the mistake is committed. Delaying the implementation of direct punishment will lose its merits. The same is true when delaying giving gifts to children;

c. Punishment is given after the child is reminded of his mistakes, and he is given the opportunity to first escape from being rude. Also when he keeps making mistakes after things have been fixed, then new punishments can be applied;

d. As much as possible to minimize the application of punishment. The punishment should be given in stages, from lenient to harsh. Some children do not need more than a warning to be deterred, therefore the character of each child needs attention; 
e. When carrying out punishment, parents, or educators must be calm and patient. Avoid feelings of resentment and desire to retaliate;

f. As much as possible stay away from threatening language, because threats might scare the child, or even make him believe that the threat is only a bluff;

g. Punishment should not last long so that it torments the child. In any condition it is not justified to hit his face, because of the personality and glory that Allah SWT. created in him would be wasted;

h. It is not justified to punish a child in the presence of his friends, competitors or opponents;

i. The punishment of beating (physical violence) may only be carried out as an ultimum remedium.

In addition, there are also matters related to methods of punishing children in Islamic family law

a. Parents or educators must stay away from threatening children with things that are not possible. These kinds of threats lose their impact on the child;

b. Parents or educators are obliged to make efforts so that everything returns to normal immediately after the execution of the sentence;

c. Parents or educators are obliged to avoid the perception that punishment is a frightening act for children, in which case parents or educators are also prohibited from lying;

d. Parents or educators must show assertiveness through tone of voice, but not by screaming. As much as possible, parents or educators must keep calm; e. Parents or educators should not compare children with other children;

f. Parents or educators must think about the effect of punishment to be applied to children, because errors in choosing the method of punishment will make children's behavior worse.

In addition, there are also things that need to be considered in physical punishment (beating), namely:

a. Parents or educators do not hit after promising not to hit, the goal is so that children do not lose trust in their parents or educators;

b. Prior to doing physical punishment (beating), give the child a chance, especially if the mistake he did was the first time he committed it;

c. If it is necessary to carry out corporal punishment, parents or educators must not do it in front of their loved ones;

d. Corporal punishment was not carried out until it hurt, let alone cause disability or scarring. Parents or educators must stay away from blows against vital body parts such as face, head, stomach, chest, and back;

e. Corporal punishment is not carried out with dangerous tools, such as shoes or sandals. And it is not justified to raise the hand beyond the normal limit in hitting, the goal is that the pain arising from the blow does not multiply;

f. Parents or educators are not allowed to criticize children when they do physical punishment, including not forcing them to apologize before they feel calm so that they are not humiliated;

g. Corporal punishment in the form of 
beatings must not be more than ten strokes, and must not be carried out at the same place over and over again.

h. Parents or educators must create the perception that corporal punishment is done for their good.

Parents or educators must understand well about the terms and methods of carrying out punishment in the form of physical and psychological violence against children. Even though the law has a tendency to prohibit acts of violence against children, sanctions for both physical and psychological violence are still needed to correct children's mistakes.

After understanding the causes of permissibility of violence in children's education, including examining the syar'i arguments that allow violence as a sanction, and knowing the limits of tolerance of Islamic law in violence against children, the researchers can conclude that physical violence or spanking is not one thing. the only way out to make someone good, sometimes people can change to be good only with gentle words, direction, and guidance. However, a person can become good after receiving a reproach (psychic violence), even with a beating (physical violence) that is more than mild. One thing is certain that each has its own way which when applied in the right time and place with the right method will produce good results in the future.

\section{Conclusion}

Based on the comparisons described in the discussion, there are some similarities and differences between Islamic family and positive law with regard to child protection, namely that Islamic family and positive law both view the problem of handling and protecting children as an urgent issue to be noticed carefully. Islamic family and positive law differ in several areas including the definition of the term "child", violence against children, physical and psychological punishment against children, and actions against perpetrators of violence. Positive law states that all forms of violence against children are a criminal offense, but Islamic family law considers that violence against children is not always a form of offense. Islamic family law emphasizes the context of physical and psychological violence, in addition to paying attention to the textual texts contained in the verses of the Al-Qur'an and hadith.

There are limits to acts of both physical and psychological violence as a preventive and repressive measure against children, according to the provisions of Islamic family law. Physical violence is only allowed as a last option for emergency repairs, if there is no other way to correct the child's mistakes. As for psychological violence in the form of strong reprimands and threats, it is still necessary to discipline children. Physical violence carried out as an ultimum remedium can only be carried out with signs that have been determined according to the Islamic family ( $f q h)$ as described in the discussion above.

\section{References}

Andiko, Toha. "Kekerasan Dalam Rumah Tangga Dan Sanksinya Perspektif Hukum Islam (Studi Kritis UU No. 23 Tahun 2004 Tentang Penghapusan Kekerasan Dalam Rumah Tangga)", Manhaj: Jurnal 
Penelitian dan Pengabdian Masyarakat, Vol. 6, No. 3, 2017.

Andiko, Toha. "Reinterpretasi Sanksi Pidana Islam (Studi terhadap Pemikiran Prof. KH. Ibrahim Hosen, LML)", Jurnal Madania, Vol. XVII, No. 2, Desember 2014.

Bayanuni, Muhammad Abdul Fatah al-. Fikih Darurat: Pegangan Ilmiah Menjawab Persoalan Khilafiah, Jakarta: Turos, 2018.

Bukhari, Abu Abdullah Muhammad bin Ismail al-. Ensiklopedi Hadits Jilid II: Shahih Bukhari 2, Jakarta: Almahira, 2012.

Departemen Agama Republik Indonesia, Al-Qur'an dan Tafsirnya (Edisi yang Disempurnakan), Jakarta: Lembaga Pencetakan Al-Qur'an Departemen Agama, 2009.

Djazuli, A. Kaidah-Kaidah Fikih, Jakarta: Kencana Prenada Media Group, 2011.

Fitriani, Ifa Latifa. "Islam Dan Keadilan Restroratif Pada Anak Yang Berhadapan Dengan Hukum", IN RIGHT Jurnal Agama dan Hak Azasi Manusia, Vol. 2, No. 1, 2012.

Hendra, Rio. "Penerapan Keadilan Restoratif Di Indonesia Bagi Anak Yang Sedang Berhadapan Hukum", Jurnal Surya Kencana Dua: Dinamika Masalah Hukum dan Keadilan, Vol. 5, No.2, Desember 2018.

Jaziri, Abu Bakar Jabir al-. Minhajul Muslim, Solo: Pustaka Arafah, 2014.

Limbat, Taisja. "Perlindungan Anak Terhadap Kekerasan Menurut Undang-Undang Penghapusan Kekerasan Dalam Rumah Tangga”, Jurnal Lex Crimen, Vol. III, No. 3, Mei-Juli 2014.

Mahalli, Imam Jalaluddin al-. dan Imam Jalaluddin as-Suyuthi, Terjemahan Tafsir
Jalalain Berikut Asbaabun Nuzuul (Jilid 1), Bandung: Sinar Agung Algensindo, 2006.

Nainggolan, Samuel Fresly. "Faktor-Faktor yang Mempengaruhi Penjatuhan Sanksi Pidana Terhadap Anak Nakal”, Jurnal Mahupiki, Vol. 2, No. 1, Agustus 2013.

Naisaburi, Muslim bin al-Hajjaj al-Qusyairi an-. Ensiklopedia Hadits Jilid IV: Shahih Muslim 2, Jakarta: Almahira, 2011.

Qarni, 'Aidh al-. Ensiklopedi Dalil Hukum, Jakarta: Pustaka Samudera Ilmu, 2005

Quthb, Sayyid. Tafsir Fi Zhilalil Qur'an: Di Bawah Naungan Al-Qur'an (Jilid 2), Jakarta: Gema Insani, 2011.

Rianawati, "Perlindungan Hukum Terhadap Kekerasan Pada Anak", RAHEEMA: Jurnal Studi Gender dan Anak, Vol. 2, No. 1, 2015.

Rifa'i, Muhammad Nasib ar-. Ringkasan Tafsir Ibnu Katsir (Jilid 1), Jakarta: Gema Insani, 2009.

Rosyid, Muhammad Aenur, dkk. "Alternatif Model Penanganan Anak Yang Berkonflik dengan Hukum Melalui Family Group Conferencing (Analisis Yuridis UndangUndang Republik Indonesia Nomor 11 Tahun 2012 Tentang Sistem Peradilan Pidana Anak)", Jurnal Universitas Brawijaya, Vol. 3, No. 2, Desember 2013.

Shihab, Quraish. Tafsir Al-Mishbah: Pesan dan Keserasian Al-Qur'an (Volume 2), Tangerang: Lentera Hati, 2008.

Sitanggang, Betania Fransiska, Irma Cahyaningtyas. "Penanganan Perkara Anak Dalam Perspektif Jaksa Penuntut Umum", Jurnal Pembangunan Hukum, Vol. 2, No. 1, 2020.

Suwaid, Muhammad Nur Abdul Hafizh. 
Prophetic Parenting: Cara Nabi Mendidik Anak, Yogyakarta: Pro-U Media, 2010.

Undang Undang Nomor 35 Tahun 2014 tentang Perubahan atas Undang Undang Nomor 23 Tahun 2002 tentang Perlindungan Anak.
Usman, Muchlis. Kaidah-kaidah Ushuliyah dan Fiqhiyah, Jakarta: PT. RajaGrafindo Persada, 2009.

Yusdani. Menuju Fiqh Keluarga Progresif, Yogyakarta: Kaukaba Dipantara, 2015

Zaidan, Abdul Karim. Al-Wajiz, Jakarta: Pustaka Al-Kautsar, 2012. 